NASA Technical Memorandum 86443

\title{
INFLUENCE OF INTERFACE PLY ORIENTATION ON FATIGUE DAMAGE OF ADHESIVELY BONDED COMPOSITE JONTS
}

\section{W. S. JOHNSON AND S. MALL}

\section{JUNE 1985}

LIRIARY RAPY

$$
\text { JUL } 2: \text { isó }
$$

LANGLEY FES $\cong$ ARTCHA CLNTER

LIBRARY, NASA

HAMIPTON, VIRGIH:A

\section{N/Sก}

National Aeronautics and

Space Administration 


\section{SUMMARY}

An experimental study of cracked-lap-shear specimens was conducted to determine the influence of adherend stacking sequence on debond initiation and damage growth in a composite-to-composite bonded joint. Specimens consisted of quasi-isotropic graphite/epoxy adherends bonded together with either FM-300 or EC 3445 adhesives. The stacking sequence of the adherends was varied such that $0^{\circ}, 45^{\circ}$, or $90^{\circ}$ plies were present at the adherend-adhesive interfaces. Fatigue damage initiated in the adhesive layer in those specimens with $0^{\circ}$ and $45^{\circ}$ interface plies. Damage initiated in the form of ply cracking in the strap adherend for the specimens with $90^{\circ}$ interface plies. The fatigue-damage growth was in the form of delamination within the composite adherends for specimens with the $90^{\circ}$ and $45^{\circ}$ plies next to the adhesive, while debonding in the adhesive resulted for the specimens with $0^{\circ}$ plies next to the adhesive. Those joints with the $0^{\circ}$ and $45^{\circ}$ plies next to either adhesive had essentially the same fatigue-damage-intiation stress levels. These stress levels were 13 and 71 percent higher, respectively, than those for specimens with $90^{\circ}$ plies next to the EC 3445 and FM-300 adhesives.

Key Words: adhesive bonding, composite material, debonding, delamination, stacking sequence, fatigue, fatigue mechanics. 


\section{INTRODUCTION}

The weight advantages of composite structures are frequently eroded by using mechanical fasteners. Adhesive bonding may be a desirable alternative to mechanical fasteners in composite structures. To utilize bonded joints efficiently and reliably, a complete understanding of their failure mechanism under different loading conditions is needed. Several studies report on the static strength of adhesively bonded composite joints (e.g., see Ref. 1); however, very little information is available on their fatigue behavior. In a previous study [2] an experimental program was undertaken to identify and understand the mechanics of the possible modes of fatigue-damage propagation in adhesive joints. It was found that cyclic debond rates correlated better with the sum of the peel-plus-shear energy-release rates than with either mode separately. However, in that study the bonded surfaces of the composites were of $0^{\circ}$ orientation only. In actual structures a variety of interfacial fiber orientations would be used. Consequently, the present study was pursued to extend the work in Refierence 2 to include interfaces of $45^{\circ}$ and $90^{\circ}$ plies in addition to those of $0^{\circ} \mathrm{ply}$. This investigation focused on fatigue-damage propagation under mixed-mode conditions (i.e., shear and peel modes). Threshold loads for fatigue-damage initiation were also determined. In a previous study by the authors [3], it was shown that the maximum cyclic stress for no debond initiation can be used for bonded systems to determine a no-growth threshold total strain-energy release rate $G_{t h}$. The $G_{t h}$ is an important design parameter. The authors have demonstrated a fracture mechanics approach for designing a bonded system utllizing this no-growth threshold $G_{t h}[3]$. For this purpose, the cracked-lap-shear spectmens tested in the program were analyzed with the finite-element program GAMNAS [4] to determine the strain-energy release rate for a given geometry, debond length, and 
applied load. From this analysis and from the experimental data, $G_{\text {th }}$ was determlned for the debond inttiation in the adhesive for the different interface ply orientations.

....

EXPERIMENTAL PROCEDURE

Test Specimens

The cracked-lap-shear specimen (CLS) shown in Fig. 1 was used in the present study. Two bonded systems were studied: Narmco (T300/5208) graphite/epoxy* adherends bonded with either 3M Co. EC 3445 adhesive or with American Cyanamid Co.* FM-300 adhesive. The properties of the adhesives and of the graphite/epoxy are given in Tables 1 and 2, respectively. The EC 3445 adhesive is a thermosetting paste with a cure temperature of $121^{\circ} \mathrm{C}$; specimens were fabricated by conventional secondary bonding procedures. On the other hand, the FM-300 is a modified epoxy adhesive supported with a carrier cloth and has a cure temperature of $177^{\circ} \mathrm{C}$; specimens were fabricated by co-cure, whereby adherends were cured and bonded simultaneously. The bonding processes followed the manufacturer's recommended procedures for each adhesive. The nominal adhesive thickness was 0.10 and $0.25 \mathrm{~mm}$ for the EC 3445 and FM-300, respectively.

For each adhesive system, three different lay-ups of the adherends were fabricated and tested. The lay-ups are given in Table 3. This arrangement provided three sets of specimens with $0^{\circ}, 45^{\circ}$, or $90^{\circ}$ plies at the adherendadhesive interface for each adhesive.

* Use of trade names or manufacturers does not consitute an official endorsement, either expressed or implied, by the National Aeronautics and Space Administration. 


\section{Testing Procedure}

The test program consisted of fatigue tests in a closed-1oop servohydraulic test machine at a frequency of $10 \mathrm{~Hz}$. In all tests, constantamplitude cyclic loads were applied at a load ratio of 0.1 . Friction grips were used, and the grips and load train were considered to be sufficiently stiff to assume fixed-fixed loading conditions on the specimen.

- Tests were conducted on the strap adherend to establish the minimum applied cyclic tensile stress that would cause debond initiation and/or adherend failure for each lay-up. To this end, virgin specimens (1.e., those with no debonding) were tested at a given load range for 1 million cycles, then inspected through dye-enhanced (zinc lodide) radiography. If there was evidence of debond initiation, the test was stopped. Otherwise, the cyclic load level was raised by approximately 10 percent. The specimen was tested for an additional 1-million cycles and then radiographed. These steps were repeated, progressiyely increasing the load range, until the specimen showed signs of debonding and/or adherend fatigue damage. This procedure allowed for more than one data point to be obtained per specimen. This testing procedure has been successfully employed by the authors to measure the threshold load for debond initiation and propagation in bonded composite joints [3].

\section{FINITE-ELEMENT ANALYSIS}

The tested cracked-lap-shear (CLS) specimens were analyzed with the finite-element program GAMNAS [4] to determine the strain-energy release rate for a given geometry, debond length, and applied load. This two-dimensional analysis accounted for the geometric nonlinearity associated with the large rotations in the unsymmetric CLS specimen.

A typical finite-element model of a CLS specimen is shown in Fig. 2. This finite-element model mesh consisted of about 1200 isoparametric 4-node 
elements and had about 2400 degrees of freedom. Each ply of composite was modeled as a separate layer of elements in the finite-element model, except for the ply at the adhesive interface, which was modeled as two layers. The adhesive thickness was modeled with four layers of elements. A multipoint constraint (indicated in Fig. 2) was applied to the loaded end of the model to prevent rotation (i.e., all the axial displacements along the ends were equal to simulate grip loading of the specimen). Plane-strain conditions were assumed in the analysis. The material properties of composite adherends and adhesives are listed in Tables 1 and 2 . The strain-energy release rate was computed with a virtual crack-closure technique. The details of this procedure are given in Ref. 4.

. To compute a debond threshold strain-energy release rate, a small debond must be assumed to exist at the location of expected debond inftiation, that is, at the end of the lap adherend. For the current computations, a debond length of $1 . \mathrm{mm}$ was assumed. This debond length was approximately the minimum size debond that could be found with the X-ray inspection technigue used during the debond initiation tests. Computations using a debond length of $0.5 \mathrm{~mm}$ resulted in calculated initiation stresses about 3 percent lower than those for.: a $1 \mathrm{~mm}$ length [3]. Thus, $G$ is not highly sensitive to the finite debond length.

\section{RESULTS AND DISCUSSIONS}

Damage Modes

In all specimens with $0^{\circ}$ and $45^{\circ}$ interface plies, the fatigue damage Initiated with cyclic debonding within the adhesive for both EC 3445 and FM-300. Thereafter, in all specimens with $0^{\circ}$ interface plies, the debond grew in a cohesive manner within the adhesive region. A detailed investigation of the mechanics of this cyclic debond growth has already been reported $[2,5]$. 
For $45^{\circ}$ interface plies, the debond grew in a combination of cyclic debonding in the adhesive and intraply failure in the $\pm 45^{\circ}$ plies of the strap adherend. The damage continued to grow in this mode for about 5 to $10 \mathrm{~mm}$ unt 11 it grew through the $\pm 45^{\circ}$ plies and reached the $0^{\circ} \mathrm{ply}$. Thereafter, fatigue failure grew in the form of cyclic delamination between the $-45^{\circ}$ and $0^{\circ}$ plies. Photographs of these modes are shown in Figs. 3 and 4 for EC 3445 adhesive. Figure 3 shows this fallure in a side view while Fig. 4 shows a radiograph in a Eront view:

For both adhesive systems in all specimens with $90^{\circ}$. interface plies, fatigue failure initiated with transverse cracking in the $90^{\circ}$ ply of the strap adherend localized at the end of the lap adherend: "The fatigue failure then grew as combined delamination and intraply failure between $\pm 45^{\circ}$ plies for about 5 to $10 \mathrm{~mm}$ until. it reached the first $0^{\circ}$ ply. in the strap adherend. Thereafter, fatigue damage grew in the form of delamination between the $-45^{\circ}$ and $0^{\circ}$ plies. This damage is shown in Figs. 5 and: 6 for a typical FM-300 specimen. Figure 5 shows the side view and Fig. 6. shows a radiograph of the front view of the fatigue damage. The damage modes are summarized in Table 4.

\section{Damage Initiation Stress}

The minimum cyclic stresses that inftiated adhesive, debonding or adherend damage within 1 million cycles are plotted in Fig. 7. These test results are also presented in Table 3. Since the number of plies was the same for the specimens with $90^{\circ}$ and $45^{\circ}$ plies at the interface, the stress levels at damage initiation may be compared. The stress levels for damage initiation in the $90^{\circ}$ interface plies are the same for both adhesives, as damage initiated in the strap adherends for these specimens. For EC 3445 specimens, the $45^{\circ}$ Interface plies allowed a no-damage stress level 13 percent higher than that of the $90^{\circ}$ interface plies. For FM-300 specimens, the $45^{\circ}$ interface plies 
allowed a no-damage stress level 71 percent higher than that of the $90^{\circ}$ interface plies.

Since the specimens with $0^{\circ}$ interface plies had a different geometry (1.e., different number of. plies in the adherends) from the $90^{\circ}$ and $45^{\circ}$ interface ply specimens, they cannot be compared on a stress basis. In this case the strain-energy release rates were calculated, as previously explained, based upon the minimum cyclic stress at damage initiation for both the $45^{\circ}$ and $0^{\circ}$ specimens (values shown in Fig. 7 and Table 3 ). This approach resulted in a threshold total strain-energy release rate, $G_{t h}$, equal to $38 \mathrm{~J} / \mathrm{m}^{2}$ and $42 \mathrm{~J} / \mathrm{m}^{2}$ for bonded systems with EC 3445 having $0^{\circ} \mathrm{ply}$ and $45^{\circ} \mathrm{ply}$ at the adhesive-adherend interface, respectively. For FM-300. the values of $G_{t h}$ were $87 \mathrm{~J} / \mathrm{m}^{2}$ and $96 \mathrm{~J} / \mathrm{m}^{2}$ for $0^{\circ}$ and $45^{\circ}$ plies, respectively. This vartation in $G_{t h}$ obtained from specimens with $0^{\circ}$ or $45^{\circ}$ plies at the interface (for both adhesive systems) was within the observed experimental scatter band. Therefore, joints with $0^{\circ}$ or $45^{\circ}$ plies at the interface had practically equal strainenergy release rate thresholds. This is expected since the fatigue faflure mechanism was the same for both cases. Further, the same is expected for all joints with any ply orientation at the interface as long as cyclic debonding in the adhesive is the cause of fatigue-damage initiation.

The effect of the interface ply orientation on the resulting $G$ value of the adhesive was less than 3 percent. The stiffness and thickness of the total adherend was the primary factor. Therefore, essentially the same minimum cyclic stress for damage initiation would be expected for $0^{\circ}$ or $45^{\circ}$ interface plies if the same specimen geometry was used (i.e., the same number of plies in a quasi-isotropic laminate).

Apparently the strength of the $90^{\circ}$ ply was so low that ply cracks developed below that stress required to create $G_{t h}$ in the adhesive. The 
static strength of a $90^{\circ} \mathrm{T} 300 / 5208$ lamina is listed as approximately $40 \mathrm{MPa}$ in ref. [6], while the strength of a $0^{\circ}$ lamina is approximately $1455 \mathrm{MPa}$. These strength. values indicate how relatively easy it is to initiate damage in a $90^{\circ}$ ply compared with a $0^{\circ} \mathrm{ply}$. Once damage started in the strap adherend, the damage propagated in the form of ply cracking, intraply damage, and delamination until a $0^{\circ}$ ply was reached. At that point the damage continued to spread by delamination between the $0^{\circ} \mathrm{ply}$ and the adjacent ply closest to the adhesive bond line, once again illustrating it is difficult for damage to grow. past a $0^{\circ}$ ply.

The debond initiation threshold values, $G_{t h}$, obtained in the present study are very close to the values of total strain-energy release rate assoclated with the debond growth rate of $10^{-6} \mathrm{~mm} /$ cycle obtained previously [2] Thus, the $G_{t h}$ assocciated with a low crack growth rate (i.e., corresponding to $10^{-6} \mathrm{~mm} / \mathrm{cycle}$ ) can be used to predict or assess the durability of bonded joints in composite structures where fatigue would occur by debond inftiation (as in the case of $0^{\circ}$ or $45^{\circ}$ interface plies).

\section{CONCLUSIONS}

An experimental study of a cracked-1ap-shear specimen subjected to constant-amplitude cyclic loading was undertaken to investigate the fatigue failure mechanism of simple composite-to-composite bonded joints. Two bond systems were studied--graphite/epoxy adherends bonded with EC 3445 adhesive in a secondary bonding procedure and the adherends bonded with FM-300 adhesive in a co-cure bonding procedure. With each bond system, specimens with three different quasi-isotropic lay-ups were tested, providing $0^{\circ}, 45^{\circ}$, or $90^{\circ}$ plies at the adherend-adhesive interface. The present study led to the following conclusions : 
1, In both bond systems, fatigue damage initiated as cyclic debonding in specimens with $0^{\circ}$ or $45^{\circ}$ plies at the adherend-adhesive interface. However, in specimens with a $90^{\circ} \mathrm{ply}$ at adherend-adhesive interface, damage occurred due to ply cracking in the $90^{\circ}$ lamina.

2. Fatigue damage grew in the form of cyclic debonding within the adhesive for specimens with a $0^{\circ} \mathrm{ply}$ at the interface. For specimens in both bond systems with $45^{\circ}$ or $90^{\circ}$ plies at the adherend-adhesive interface, fatigue damage grew in the form of intraply damage in the strap adherend until it reached the first $0^{\circ} \mathrm{ply}$, and thereafter it grew as a cyclic delamination.

3. Joints with adherend lay-ups that result in damage initiation in the adhesive (e.g., $0^{\circ}$ and $45^{\circ}$ interface plies) resulted in allowable stress levels for no damage 13 and 71 percent higher than thase joints with $90^{\circ}$ interface plies for EC 3445 and FM-300 adhesives, respectively.

4. The total strain-energy release rate threshold, $G_{t h}$, was practically the same for specimens with $0^{\circ}$ or $45^{\circ}$ fibers next to the adhesive. This is to be expected because damage started in the adhesive in both cases. This indicates that $G_{t h}$ is an adhesive material property that may be applied to different joint geometries and adherend lay-ups. These results are significant because they indicate that $0^{\circ}$ fibers do not have to be in the direction of maximum stress to achieve a maximum no-damage threshold stress level. This assumes that a safe-life design is used based on maximum design stress levels below those required to cause $G_{t h}$ in the adhesive at an assumed initial defect [3]. Care must be exercised to assure that $90^{\circ}$ (or near $90^{\circ}$ ) plies are not adjacent to the bond line in the direction of 
principal stress, or else delamination in the composite adherend will result unless lower design stress levels are used. 
1. F. L. Matthews, P. F. Kilty, and E. W. Godwin, "A Review of the Strength of Joints In Fiber-Reinforced Plastics, Part 2--Adhesively Bonded Joints", Composites, 13.(1), 29 (1982).

2. S. Mall, W. S. Johnson, and R. A. Everett, Jr., "Cycllc Debonding of Addhesiṿely Bonded Composites", NASA TM-84577, November 1982.

3. W. S. Johnson, and S. Ma11, "A Fracture Mechanics Approach for DesignIng Adhesively Bonded Joints", NASA TM-85694, September 1983.

4. B. Dattaguru, R. A. Everett, Jr., J. D. Whitcomb, and W. S. Johnson, "Geometrically-Nonlinear Analysis of Adhesively Bonded Joints", NASA TM-84562, National Aeronautics and Space Administration (1982).

5. S. Mall, and W. S. Johnson, "Characterization of Mode I and Mixed-Mode Debond Failure of Adhesively Bonded Composite Joints" to be published In ASTM Symposium STP of 7 th Conference on Composite Material Testing and Design, Philadelphia.

6. DOD/NASA Advanced Composite Design Guide, Volume IV-A: Material, Air Force Wright Aeronautical Laboratories, July 1983. 
Table 1.- Adhesive material properties [2].

\begin{tabular}{lccc} 
& \multicolumn{2}{c}{ Modulus, GPa } & Poisson's Ratio \\
& E & G & $\nu$ \\
EC 3445 (3M Company) & 1.81 & 0.65 & 0.4 \\
$\begin{array}{c}\text { FM-300 (American } \\
\text { Cyanamid Company) }\end{array}$ & 2.32 & 0.83 & 0.4
\end{tabular}

Table 2.- Graphite/epoxy ${ }^{a}$ adherend materlal properties.

\begin{tabular}{|c|c|c|c|c|}
\hline $\mathrm{E}_{1}$ & $\mathrm{E}_{2}$ & $\mathrm{G}_{12}$ & $\nu_{12}$ & $v_{23}$ \\
\hline 131.0 & 13.0 & 6.4 & 0.34 & 0.34 \\
\hline
\end{tabular}


Table 3.- TEST RESULTS

Adhesive Ply at Interface

\section{$\frac{\text { Lay-up Strap }}{\text { Lay-up Lap }}$}

EC 3445

$0^{\circ} * \quad[0 / \pm 45 / 90]_{s} /[0 / \pm 45 / 90]_{2 s}$

$45^{\circ} \quad[ \pm 45 / 0 / 90]_{2 s} /[ \pm 45 / 0 / 90]_{2 s}$

$90^{\circ}$

FM-300

$0^{\circ} *$

$\vec{\omega}$ $[90 / \pm 45 / 0]_{2 s} /[90 / \pm 45 / 0]_{2 s}$ $[0 / \pm 45 / 90]_{2 s} /[0 / \pm 45 / 90]_{s}$ $[ \pm 45 / 0 / 90]_{2 s} /[ \pm 45 / 0 / 90]_{2 s}$

$90^{\circ}$

Number of Test Specimens
Average Minimum Cyclic Stress, $\mathrm{MPa}$ $[90 / \pm 45 / 0]_{2 s} /[90 / \pm 45 / 0]_{2 s}$

4

4

4

3

4

4
78

70

62

123

106

62

*previous paper [2] 
TABLE 4.- DAMAGE MODES FOR EC 3445 AND FM-300 ADHESIVES IN CRACKED-LAP-SHEAR SPECIMENS

\begin{tabular}{|c|c|c|c|}
\hline $\begin{array}{l}\text { Interface } \\
\text { orientation }\end{array}$ & Initiation & Early growth & Later growth \\
\hline $0^{\circ}$ & \multirow{2}{*}{ Adhesive debonding } & Within adhesive & Within adhesive \\
\hline $45^{\circ}$ & & $\begin{array}{l}\text { Combination of } \\
\text { In-adhesive and } \\
\text { between } \pm 45^{\circ} \text { plies }\end{array}$ & \multirow{2}{*}{$\begin{array}{l}\text { Delamination } \\
\text { between } \\
-45^{\circ} \text { and } 0^{\circ} \text { plies }\end{array}$} \\
\hline $90^{\circ}$ & $\begin{array}{l}\text { Cracks in } 90^{\circ} \text { ply } \\
\text { In strap adherend }\end{array}$ & $\begin{array}{c}\text { Delamination and ply } \\
\text { cracking in } 90^{\circ} \text { and } \\
\pm 45^{\circ} \text { plies. }\end{array}$ & \\
\hline
\end{tabular}



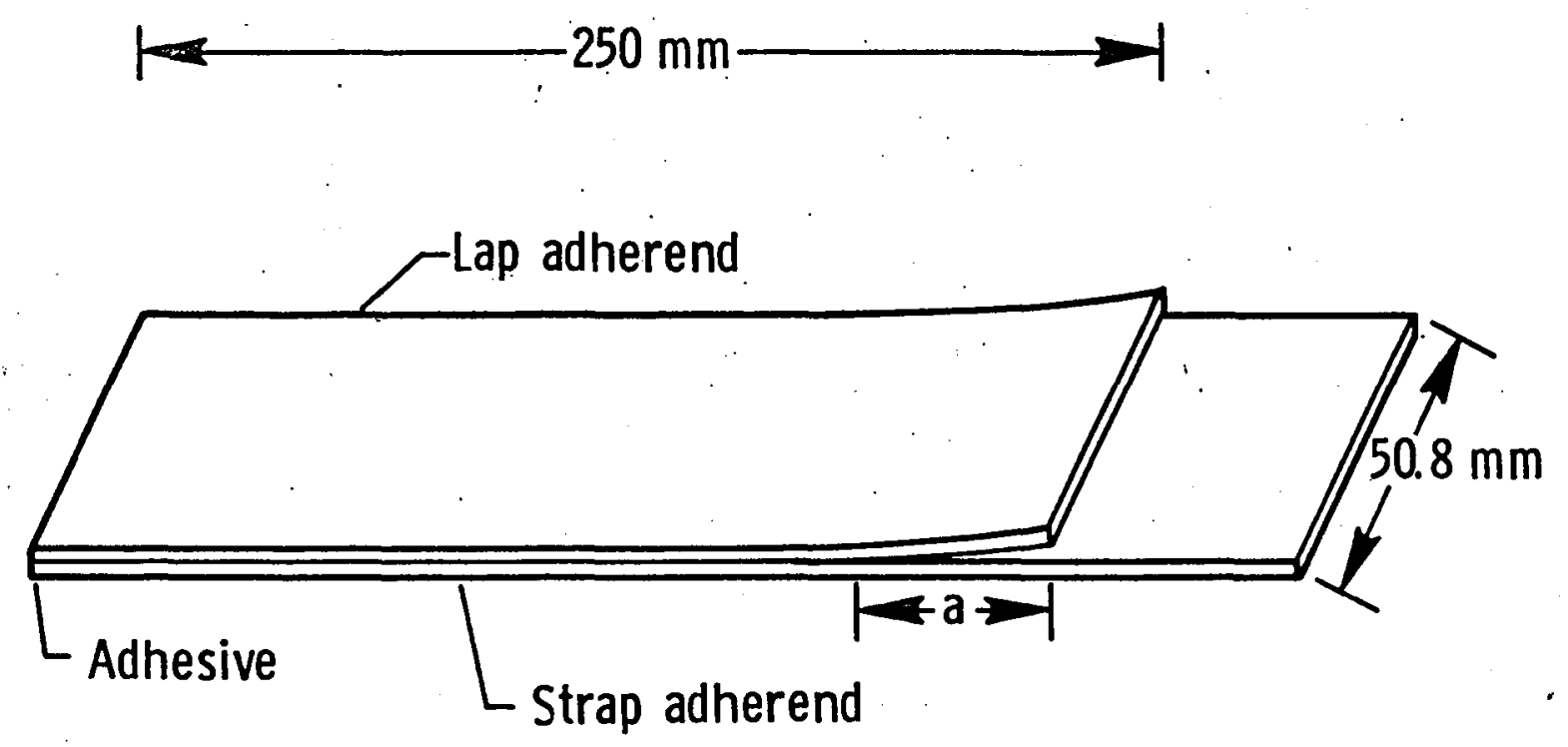
$380 \mathrm{~mm}$

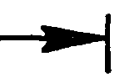

Figure 1. - Cracked-1ap-shear specimen. 


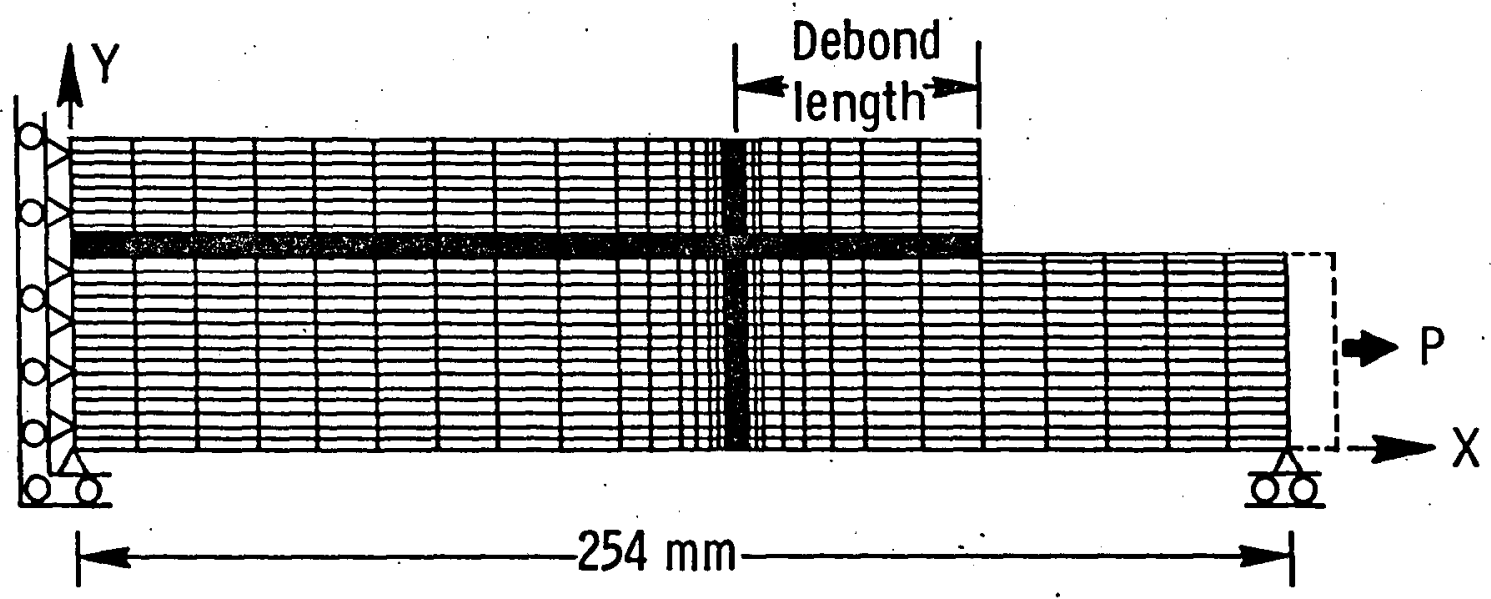

Figure 2. - Typical finite element mesh ( $\mathrm{Y}$ coordinates are magnified 20X). 


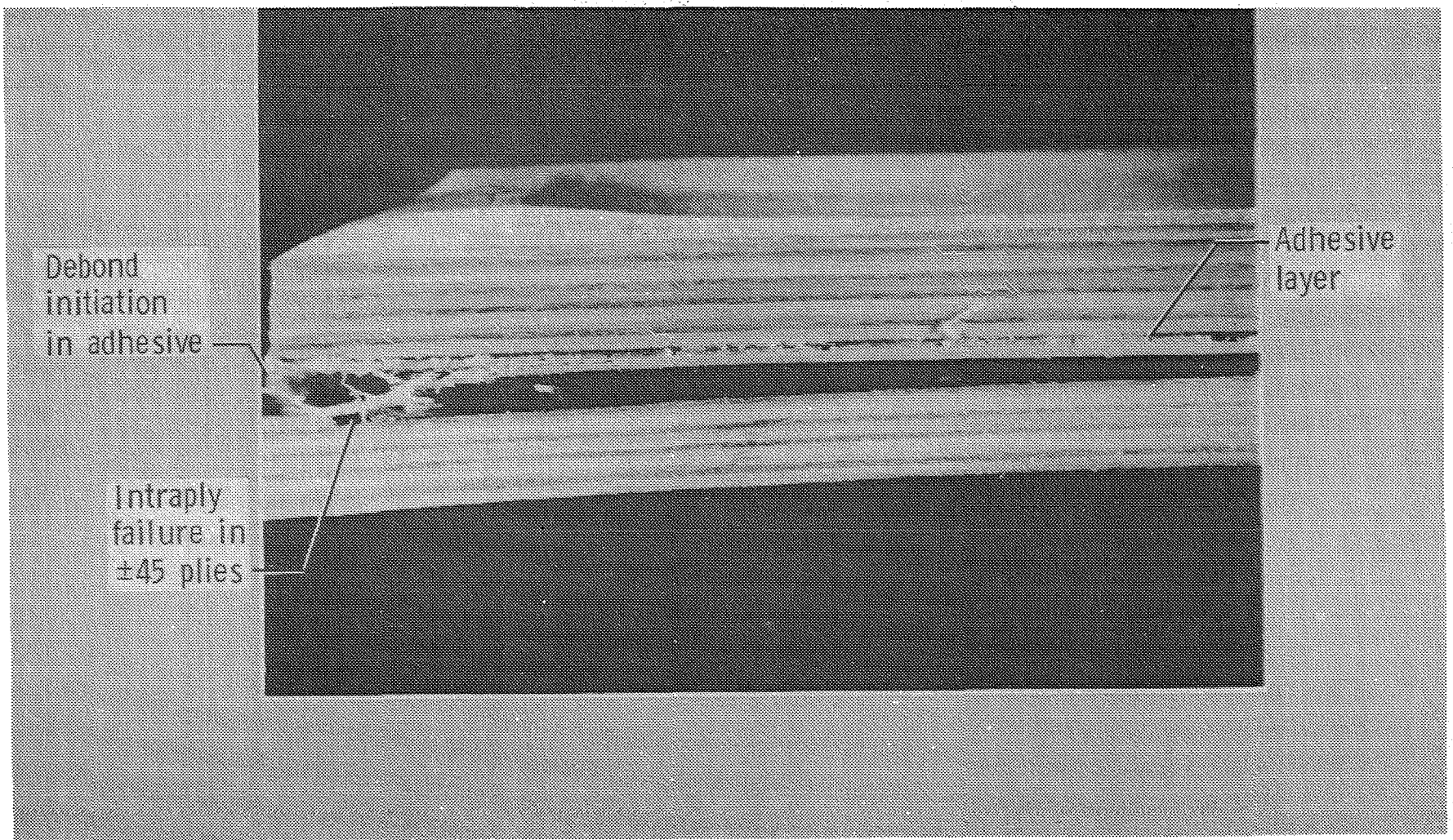

Figure 3. - Edge view of fatigue damage in the EC 3445 adhesive CLS specimen with $[ \pm 45 / 0 / 90]_{2 s}$ layup. 


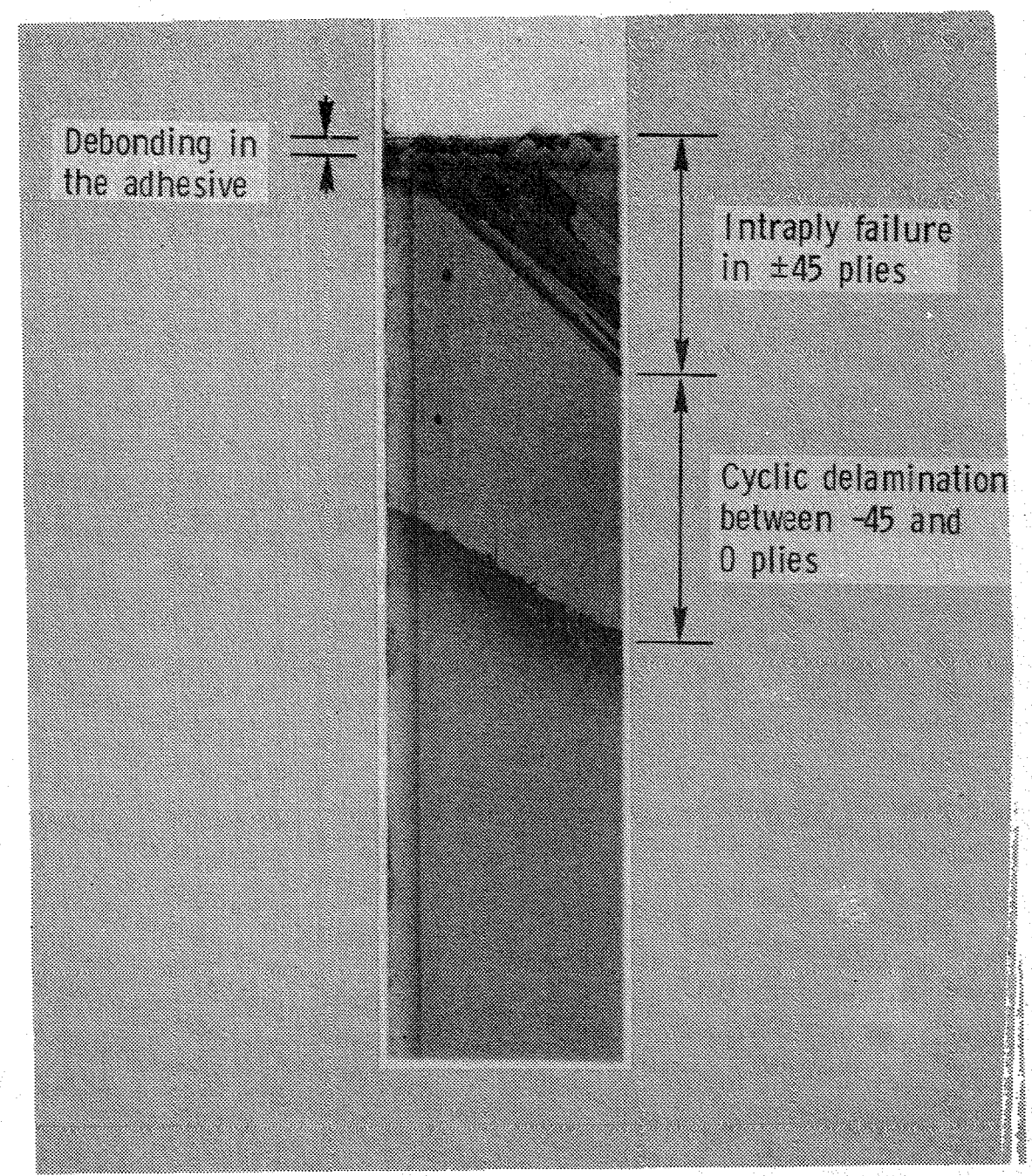

Figure 4. - Radiograph showing fatigue damage in the EC 3445 adhesive CLS specimen with

$[ \pm 4.5 / 0 / 90]_{2 s}$ layup. 


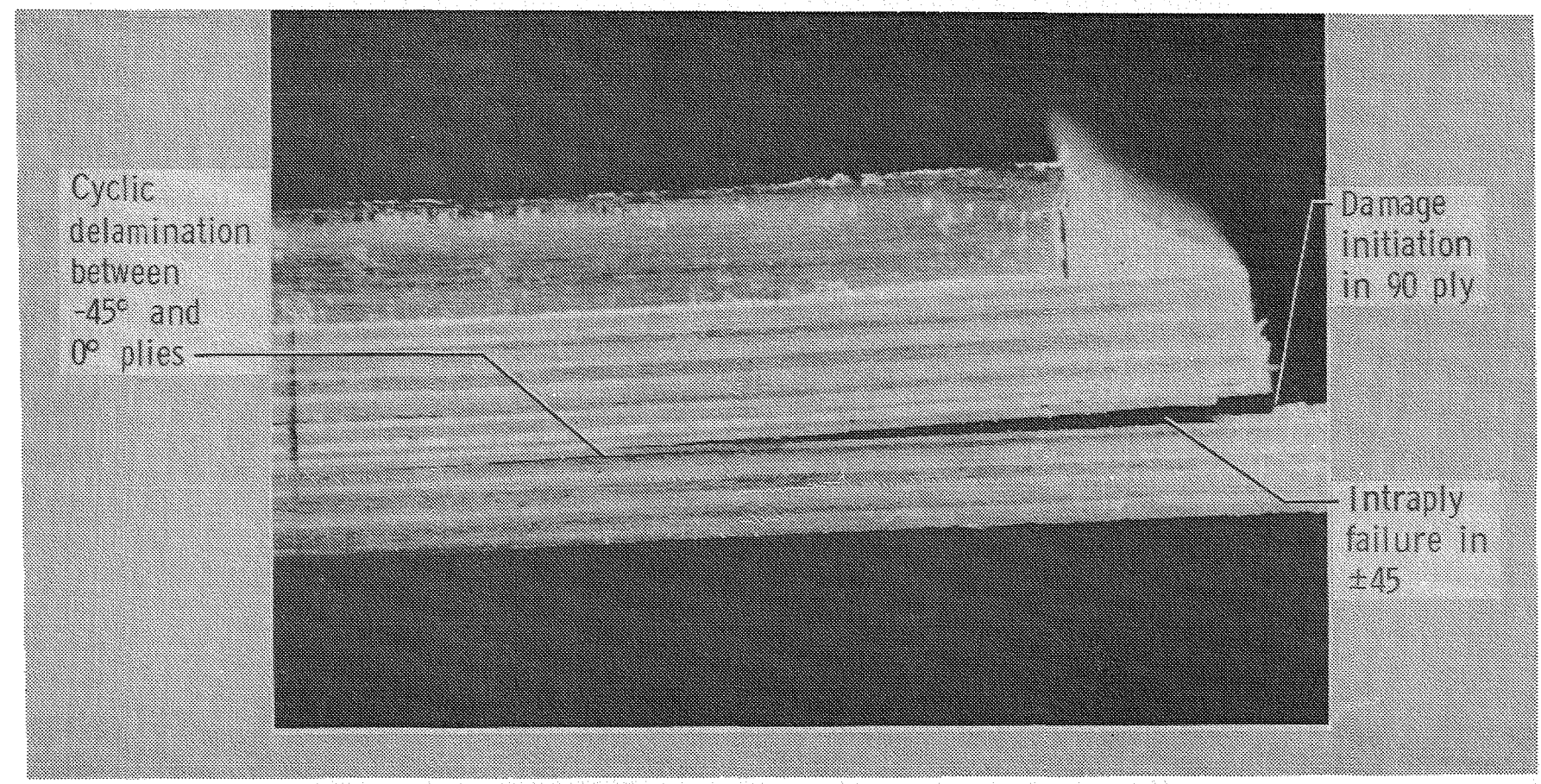

Figure 5. - Edge view of fatigue damage in the FM- 300 adhesive CLS specimen with $[90 / \pm 45 / 0]_{2 s}$ layup. 


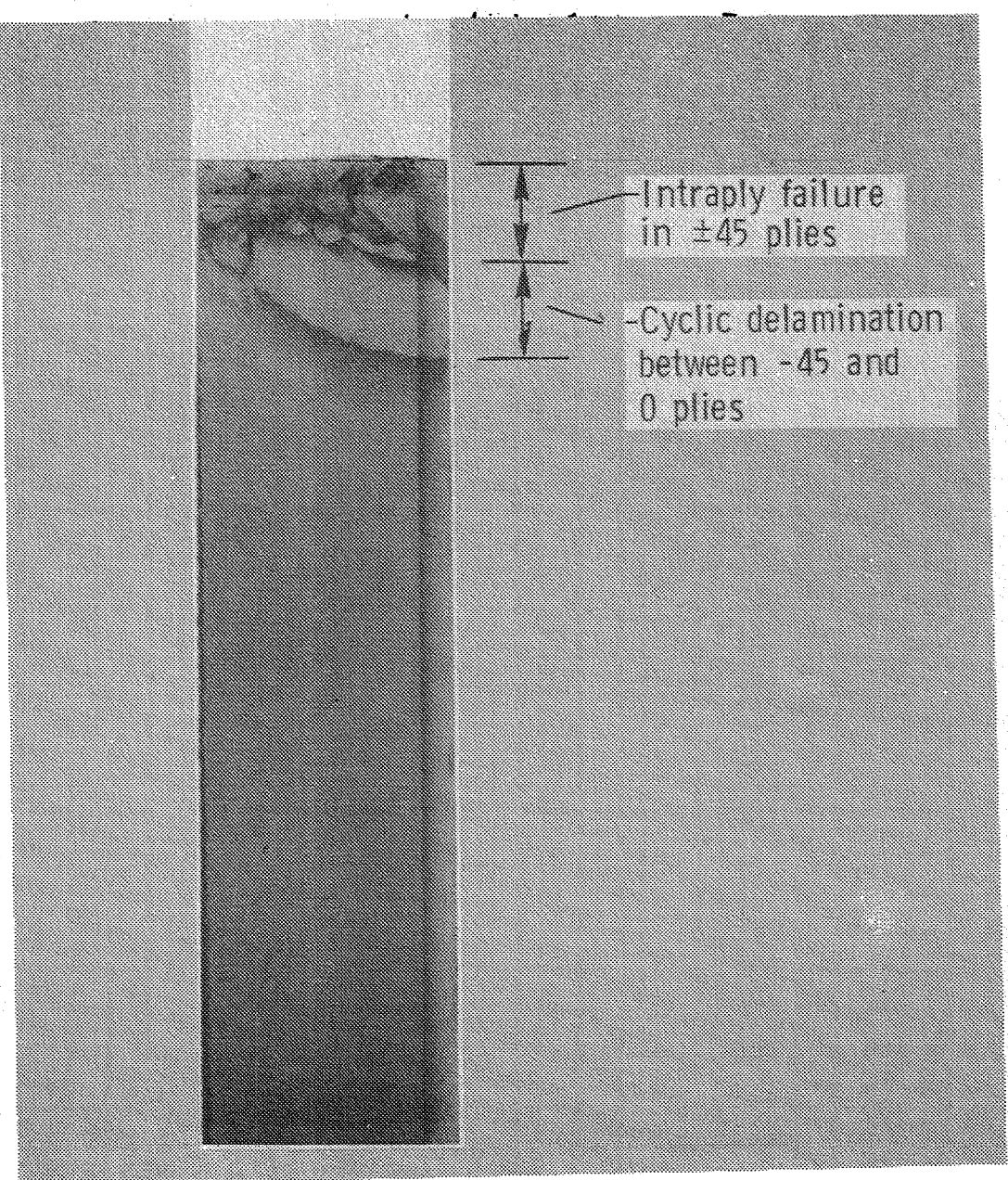

Figure 6. - Radiograph showing fatigue damage in the FM-300 adhesive CLS specimen with $[90 / \pm 45 / 0]_{2 s}$ layup. 


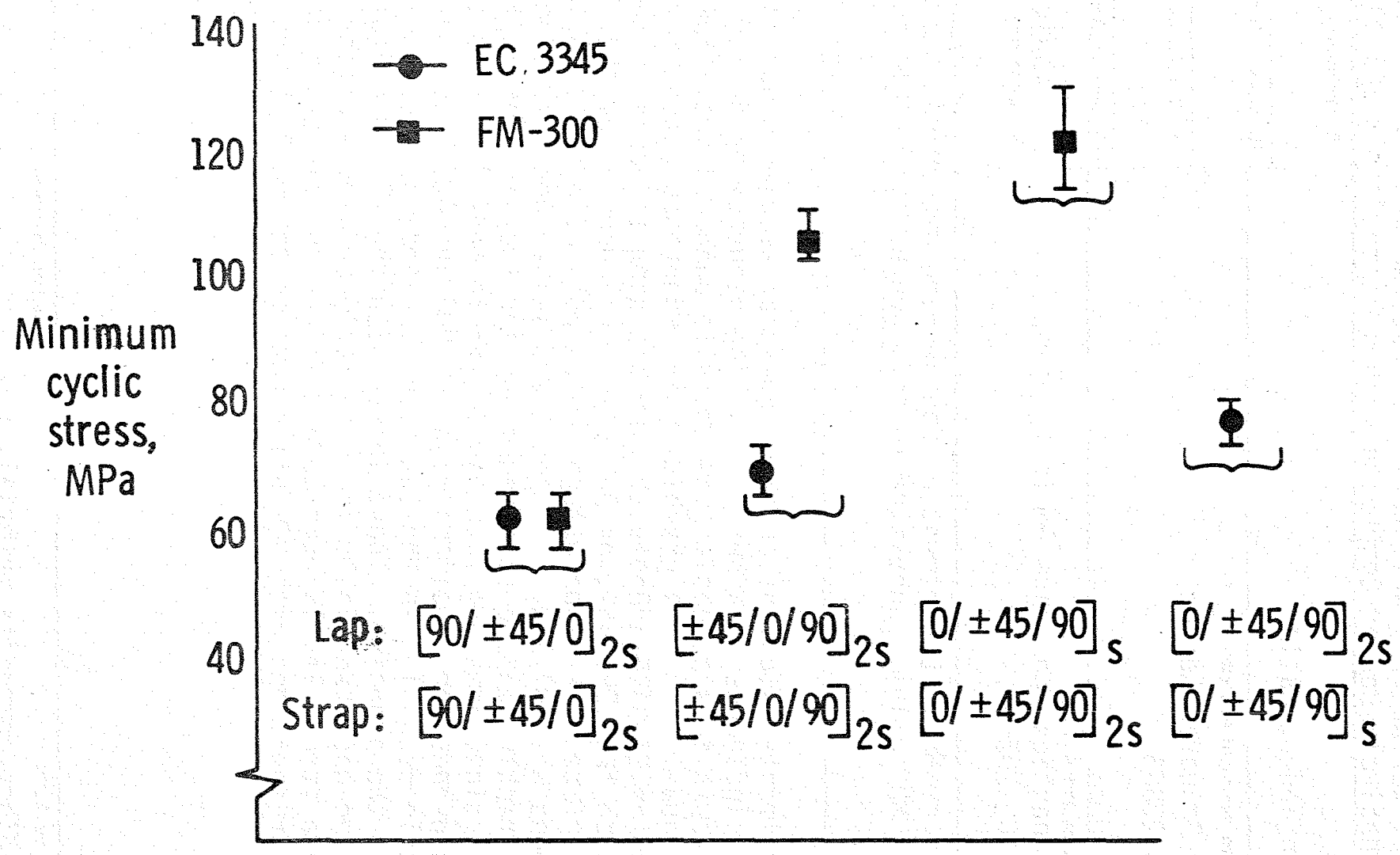

Figure 7. - Minimun cyclic stress for damage initiation in CLS specimens with various layups. $(R=0.1)$ 
紋

\begin{tabular}{|c|c|}
\hline $\begin{array}{l}\text { 1. Report No. } \\
\text { NASA TM-86443 }\end{array}$ & 3. Recipient's Catalog No. \\
\hline \multirow{2}{*}{$\begin{array}{l}\text { 4. Title and Subtitle } \\
\text { Influence of Interface Ply Orientation on Fatigue } \\
\text { Damage of Adhesively Bonded Composite Joints }\end{array}$} & $\begin{array}{l}\text { 5. Report Date } \\
\text { June } 1985\end{array}$ \\
\hline & $\begin{array}{r}\text { 6. Perfor } \\
505 \\
\end{array}$ \\
\hline \multirow{2}{*}{$\begin{array}{l}\text { 7. Author(s) } \\
\text { W. S. Johnson and S. Ma11* }\end{array}$} & 8. Performing Orga \\
\hline & \\
\hline \multirow{3}{*}{$\begin{array}{l}\text { 9. Performing Organization Name and Address } \\
\text { NASA Langley Research Center } \\
\text { Hampton, VA } 23665\end{array}$} & \\
\hline & 11.0 \\
\hline & 13. Type o \\
\hline \multirow{2}{*}{$\begin{array}{l}\text { 12. Sponsoring Agency Name and Address } \\
\text { National Aeronautics and Space Administration } \\
\text { Washington, DC } 20546\end{array}$} & $\mathrm{um}$ \\
\hline & 14. Spon \\
\hline \multicolumn{2}{|c|}{$\begin{array}{l}\text { 15. Supplementary Notes * S. Ma11, Department of Engineering Mechanics, University of } \\
\text { Missouri, Ro11a, MO } 65401 \text {. Submitted to ASTM Journal of Composites Technology } \\
\text { and Research. }\end{array}$} \\
\hline \multicolumn{2}{|c|}{$\begin{array}{l}\text { 16. Abstract } \\
\text { An experimental study of cracked-lap-shear specimens was conducted to } \\
\text { determine the influence of adherend stacking sequence on debond initiation } \\
\text { and damage growth in a composite-to-composite bonded joint. Specimens } \\
\text { consisted of quasi-isotropic graphite/epoxy adherends bonded together with } \\
\text { either FM- } 300 \text { or EC } 3445 \text { adhesives. The stacking sequence of the adherends } \\
\text { was varied such that } 00,450 \text {, or } 900 \text { plies were present at the adherend- } \\
\text { adhesive interfaces. Fatigue damage initiated in the adhesive layer in } \\
\text { those specimens with } 00 \text { and } 45^{\circ} \text { interface plies. Damage initiated in the } \\
\text { form of ply cracking in the strap adherend for the specimens with } 900 \text { interface } \\
\text { plies. The fatigue-damage growth was in the form of delamination within the } \\
\text { composite adherends for specimens with the } 90^{\circ} \text { and } 45^{\circ} \text { plies next to the } \\
\text { adhesive, while debonding in the adhesive resulted for the specimens with } 0^{\circ} \\
\text { plies next to the adhesive. Those joints with the } 0^{\circ} \text { and } 45^{\circ} \text { plies next to } \\
\text { either adhesive has essentially the same fatigue-damage-initiation stress } \\
\text { levels. These stress levels were } 13 \text { and } 71 \text { percent higher, respectively, } \\
\text { than those for specimens with } 90^{\circ} \text { plies next to the EC } 3445 \text { and FM-300 adhesives. }\end{array}$} \\
\hline
\end{tabular}

17. Key Words (Suggested by Author(s))

18. Distribution Statement

adhesive bonding, composite material,

debonding, delamination, stacking

sequence, fatigue, fatigue mechanics

Unclassified-Unlimited

Subject Category 39

\begin{tabular}{|c|c|c|c|}
\hline $\begin{array}{c}\text { 19. Security Classif. (of this report) } \\
\text { Unclassified }\end{array}$ & $\begin{array}{c}\text { 20. Security Classif. (of this page) } \\
\text { Unclassified }\end{array}$ & $\begin{array}{c}\text { 21. No. of Pages } \\
22\end{array}$ & $\begin{array}{r}\text { 22. Price } \\
A 02\end{array}$ \\
\hline
\end{tabular}


End of Document 